\title{
Gender inequality and the professionalisation of accountancy in the UK from 1870 to the interwar years
}

Authors: C. Evans and N. Rumens

\begin{abstract}
Drawing on historical data largely relating to Price Waterhouse Coopers (PwC), this article examines the early professionalisation of accountancy as a gendered process. Mobilising Acker's (1990) theory of the ideal worker, this article highlights articulations of an ideal professional accountant, coded as male and masculine in the gendering of professional skills and knowledge, image management, networking and social class. Additionally, social changes such as WW1 reshaped the masculine nature of the ideal professional accountant in $\mathrm{PwC}$, emphasising a militaristic masculinity, to support the war effort. While women were temporarily employed in accountancy clerical jobs in wartime, this does not appear to have regendered PwC as an organisation inclusive of femininity and women. However, it is noted that some middle-class women challenged exclusionary professional practices within accountancy. The implications of the gendered aspects of the professionalisation of accountancy are discussed throughout the article.
\end{abstract}

Keywords: Gender; gender inequality, men, women, masculinity, professions, professionalisation, accountancy, interwar period.

\section{Introduction}

The representation of women in the UK accountancy profession has followed a slow and uneven upward trajectory, influenced by factors such as labour market demands, resistance from the accountancy profession to the employment of women and the process of 
professionalisation (Crompton and Lyonette, 2011; Khalifa, 2013; Kokot, 2015; Shackleton, 1999; Whiting, Gammie and Herbohn, 2015). While the chequered history of women's participation in the UK accounting profession has attracted the scrutiny of feminists and business and accounting historians (Lehman 1990; Kirkham and Loft, 1993; Walker, 2003, 2008, 2011), the relationship between gender and the professionalisation of accountancy in England and Wales from 1870 to the interwar period has received less scholarly attention compared to other periods (Walker, 2011). This represents a missed opportunity for business historians interested in accountancy, gender and gender inequality. As this article explores, in addition to traditionally recognised professional ideals (e.g. possessing specialist knowledge and technical competence, displaying ethical behaviour), other factors are also important such as social class and gender (Witz, 1992). Professionalisation has been read as a gendered process, as the qualities and behaviours associated with being a 'professional' are, according to feminist theorists, largely synonymous with men's practices and masculinity (Witz, 1992). For example, in the context of accountancy, Khalifa (2013) argues that working long and unpredictable hours, as well as socialising with clients, has informed accountants' understandings of what the professional accountant is expected to undertake. These aspects of professionalisation have gendered implications, as the burden of household and caring duties have largely been shouldered by women reducing their ability to respond flexibly to demands for long and unsocial working hours, leaving them at a career disadvantage (Pilcher, 1999; Crompton and Lyonette, 2006, 2011).

The relationship between gender and the professionalisation of accountancy in the UK from 1870 to the interwar years warrants examination because some of the societal changes within this time period were enormously influential. For instance, WW1 created labour shortages that opened up employment opportunities for women in accountancy. From 1870 to the beginning of WW1, women occupied few positions within the accountancy profession 
(Kirkham and Loft, 1993), but, during wartime, women entered accountancy firms to carry out work which clerks, articled clerks and even professional accountants had previously performed. However, this influx of women into the accountancy profession was temporary, as accountancy firms did not adopt the type of post war labour force strategies that retained women as a key component of the workforce, such as those implemented by the Post Office (Crowley, 2016). While the entry of women into accountancy during wartime increased the number of women in the profession, it did not re-gender the accountancy profession in the $\mathrm{UK}$ as more accepting of femininity and women. Indeed, this article's examination of the professionalisation of accountancy during wartime, and during the years dating back to 1870, highlights the emergence and circulation of an ideal professional accountant construct coded as male and masculine.

During this time period, other social changes influenced women's participation in the world of work in general, and the accountancy profession in particular. For example, the imposition of the marriage bar for Civil Service workers, introduced in the latter half of the nineteenth century (Crowley, 2016), forced women to resign from the workplace upon marriage. One deleterious effect of the marriage bar was the confinement of married women to the domestic sphere, where middle-class women in particular were encouraged to take up the 'profession' of household accountancy (Walker, 1998). It is noteworthy that accountancy firms voluntarily enforced the marriage bar (Lehman, 1990; Kirkham and Loft, 1993), which can be read as another means by which the ideal professional accountant was reproduced as male and masculine.

From the early days of professionalisation to date, the number of male compared to female members of the Institute of Chartered Accountants in England and Wales (ICAEW) has been disproportionately higher (Ciancanelli, Gallhofer, Humphrey, and Kirkham, 1990; Evans, 2016). However, there was a surge in the growth of female members joining the ICAEW in the 
period from 1980 to 1990 , when UK female membership increased from 2,971 to 10,560 (an increase of over 250\%) (Evans, 2016). This may be explained by the significant growth during the 1980s in the size and scope of the services offered by the largest accountancy firms (Willmott, 1986) that raised the demand for accountants, met partly by recruiting women (Suddaby, Cooper and Greenwood, 2007). Still, by 1990, women represented just $11.1 \%$ of the total ICAEW membership of 94,938 (Evans, 2016, 384). From there on, women continued to join the ICAEW and female chartered accountants represented $28 \%$ of total membership in 2017 (FRC, 2018). In broad terms, the accountancy profession compares unfavourably to law and medicine in terms of female membership (Nicolson, 2005; Witz, 1992). In 1990, 23\% of the legal profession in England and Wales were women (Aulakh, Charlwood, Muzio, Tomlinson, and Valizade, 2017, 12), although this had risen to 50.8\% in 2017 (Law Society, 2018). Similarly, in the medical profession, $25 \%$ of active practitioners were women in 1990 (Elston, 1993), rising to 47\% in 2017 (GMC, 2017).

Considering the above, this article examines the relationship between gender and the professionalisation of accountancy in the UK from 1870 to the interwar period. Adding to historical research on gender and the professionalisation of accountancy, this article draws on Acker's (1990) feminist theory of the ideal worker to explore how the professionalisation of accountancy articulated, reproduced and circulated notions of the ideal professional accountant. One important feature of this contribution is that articulations of the ideal professional accountant are gendered and embedded in social class, principally a middle-class male image of an accountant that underpinned a belief that it was men who should be dominant in the accountancy profession. Furthermore, it was largely middle-class women who were able to access the accountancy profession during wartime due to their ability to meet the educational standards accountancy firms demanded, but their presence and contributions to the profession do not appear to have ruptured the notion of the ideal accountant as male and masculine. The 
following two sections outline the feminist theory and methods used to collect and analyse the historical data presented in this article.

\section{Conceptualising gender and the ideal worker}

This article mobilises feminist theory to conceptualise gender as a social construct that is historically patterned. Put differently, gender is not understood as an immutable property of the individual. Gender is socially constructed within relations of power that turn attention away from analysing fixed biological differences between men and women, toward historically and culturally contextualising the gender category of 'woman' (Burr, 2015; Scott, 1986). Scott (1986) argues how gender can highlight meanings ascribed to masculinity/femininity and be defined as power relations that reproduce gender inequalities, which historians, including those in the accountancy domain, have often ignored (Haynes, 2008). Crucially, Scott's (1986) treatment of gender as a category of historical analysis problematises and historicises concepts and practices defined as or assumed to be gender neutral (Durepos, McKinlay and Taylor, 2017). The gender neutral workplace, predicated on a belief that gender is imported by men and women into a neutral workplace, is debunked by the feminist argument that places of work are already gendered. Research shows that career pathways in accountancy are not gender neutral but gendered as they privilege a linear and uninterrupted career trajectory that has traditionally been associated with men and men's work practices (Whiting, Gammie and Herbohn, 2015).

Acker's (1990) ideal worker theory has been widely used in feminist research on gender inequalities in organisations (Sayce, 2012), and deployed here because it enables an 
examination of the gendered dynamics in the professionalisation of accountancy. According to Acker (1990), workplace cultures, practices and policies reproduce a gendered construct of the ideal worker: someone who is 'totally dedicated to the work and who has no responsibilities for children or family demands other than earning a living.' (2006, 448). For Acker, the ideal worker is gendered, coded as 'male' and 'masculine', leaving many women unable to achieve the desirable qualities attributed to the ideal worker construct (Williams, 2000). Organisational processes and procedures support and reproduce the ideal worker construct, with the division

of labour and organisational culture being of particular relevance for examining how the accountancy profession has restricted women's entry and participation in the workplace. Acker (1990) proposes that organisations can reflect and reproduce gender through the division of labour that encourages men to do one task and women to do others, depending upon their socially constructed roles.

\section{Methods}

The historical material this article presents relates to Price Waterhouse Coopers (PwC). In 2002, crystallising out of a series of ongoing mergers and collapses, the four largest existing accounting firms became known as the 'Big 4' (FRC, 2018). The Big 4 currently dominate the field and comprise, in descending order of size: Price Waterhouse Coopers (PwC); KPMG; Ernst \& Young; and Deloitte. In the UK, accountants employed by the Big 4 have traditionally been members of the ICAEW. PwC is the largest of the Big 4 accountancy firms and illustrates various gendered inequalities that have also beset other members of the Big 4 (Evans, 2016). PwC emerged from a series of mergers and acquisitions of smaller accountancy firms over the 
last 100 years. The largest of the firms included in the final naming of the organisation were Price Waterhouse and Coopers \& Lybrand (formerly Cooper Brothers \& Co.).

Uncovering material on the internal workings of accountancy firms is challenging, as their operations have always been shrouded in secrecy, a characteristic that is generally associated with the professional nature of accountancy (Anderson-Gough, Grey and Robson, 2005). It appears that these organisations have rarely been keen on making records available, a reticence that can be traced back to the early twentieth century (Wise, 1982). The ICAEW library, which was established formally in 1893, has an extensive collection of material on accountancy (Howitt 1966). Using the ICAEW records, the first author discovered historical material that has received very little scholarly attention to date. Additionally, the first author found a large number of accountancy firms, both big and small, had commissioned and published a history of their organisations. For this article, the principal focus is on the firms constituting $\mathrm{PwC}$, but this article also references historical literature from other accountancy organisations. This supplementary material is considered important as it provides insights into the wider gendering of the accountancy profession to demonstrate that the reproduction of gender inequality within $\mathrm{PwC}$ was and is not unique to this organisation. The published histories of accountancy firms constitute a formally sanctioned historical account of each firm (Wise, 1982), representing an illuminating record of accountancy life in the firms' own words (Wise, 1982; Allen and McDermott, 1993). While these historical texts are not impartial, they nevertheless afford empirical insights into how accountancy firms viewed the employment of men and women.

A second source of material extracted from ICAEW library records were the approved histories of both regional (Middleton, 1982) and national ICAEW bodies (Howitt, 1966). This documentation reveals what the bodies emphasised as the focus of their concerns at various times and indicates what material they have chosen to make public. Third, we include archival 
material from a leading figure in the profession, Francis W. Pixley. Pixley was a chartered accountant and barrister who served as President of the ICAEW in 1905 and was Treasurer for the Chartered Accountants Benevolent Fund, as well as author of a number of books on the subject of accountancy. He gave lectures to trainee accountants and presented at various dinners held for chartered accountants. Through his textbooks, influence on trainee accountants and prominent public roles, Pixley was responsible for cultivating a body of knowledge during the embryonic stage of the profession's development (Pixley, 1885), which helped to constitute the ideal accountant construct, illustrated in the next section.

\section{Characteristics and skills: the influence of Francis W Pixley}

Setting the scene, it is important to recognise that the occupation of 'accomptant' (Sikka and Wilmott, 1995) or accountant can be traced back to the late eighteenth century in England and Wales. This occupational role was initially unclear and the expertise required of accomptants appears to have covered a variety of areas: bookkeeper, attorney, bankruptcy auditor or executor of estates (Kirkham and Loft, 1993, 517). The growth of legislation, including the Companies Act 1862, to allow the expansion of free trade, facilitated the growth of accountancy-type services during the nineteenth century. This Act, termed 'the accountants' friend' (Sikka and Willmott, 1995), lent statutory authority to the distinction between elite accountants and others. During the mid-nineteenth century, the gradual development of a statefunded education system improved the literacy and numeracy skills of both working-class men and women. These were the very skills valued in a clerk, and the aspirant working classes saw the clerk job role as a way to improve their social position (Kirkham and Loft, 1993). The occupation of accountant remained poorly defined with little or no distinction between the work 
of an accountant and a clerk. Both jobs were classed together in a commercial, rather than professional, category in the census of England and Wales 1871 (Kirkham and Loft, 1993, 509).

In this context, the professionalisation of accountancy in the 1870s began to take shape. Elite accountants fought to establish their jurisdiction and protect it from other professions such as law. As one of the first accountancy bodies to be established, the ICAEW engaged in a project by which its members strove to establish the characteristics and skills of an accountant. In a manner similar to the medical profession (Witz, 1992), the creation of a clearly defined division of labour occurred, sustained by a hierarchy that differentiated the accountant from the bookeeper or clerk (Kirkham and Loft, 1993; Wilmott, 1986). Here, using Scott's (1986) concept of gender as a category of historical analysis, insights emerge into how the type of work undertaken in accountancy was associated with men and allied with the academic prowess given to higher class males.

The knowledge Francis W Pixley consolidated during the emergence of the profession illustrates the constitution of the ideal accountant construct. In the following quotation, Pixley was speaking at the Chartered Accountants' Student Society of London:

The foundation, therefore, of the professional training is a knowledge of book-keeping, but the mastery of this subject leaves the student only on the threshold. A first class book-keeper may not possess the qualifications to enable him to undertake the position of a second-class clerk in a professional Accountant's office, but a perfect knowledge of book-keeping is requisite for the analysis of the books of account in the simplest investigation entrusted to a Chartered Accountant. (Pixley, 1885, 20).

Pixley's lectures promulgated the idea that the ability to perform bookkeeping was the first step on the way to becoming an accountant: 
A knowledge, however, of book-keeping is not the only qualification an Auditor should possess. It is merely the foundation on which his training is based, as it does not by any means follow that a most accomplished book-keeper, and one able to keep the Accounts of a large banking and mercantile firm, is capable of effectually auditing the books of a small retail business. The duties of a book-keeper are confined to recording the financial transactions, and his skill can go no go higher than performing these operations in a manner which combines the highest accuracy with the simplest method, the least possible labour, and the least possible consumption of time. (Pixley, 1885, 45).

In these passages, Pixley establishes a hierarchical structure in accountancy-type skills, which places clerks and bookkeepers below accountants. Clerical work had already been regarded as the preserve of men (Glew, 2016; Zimmeck, 1986), which chimes in with Pixley's idea that a male bookkeeper should be responsible for recording transactions. Between 1850 and 1914, clerical work was transformed. The percentage of women rose from $2 \%$ to $20 \%$ of the total number of clerks (Zimmeck, 1986, 154), paving the way for clerical work to be reclassified as 'women's work'. As Zimmeck (1986) points out, male clerks sought to draw a line between the intellectual clerical work of men and the mechanical clerical work of women, which was reinforced by the mechanisation of office work taking place at around this time. Notably, Pixley's hierarchy is classed in how it excludes working class men as accountants and is gendered in how it excludes women as potential accountancy workers. Female clerks were far less prevalent in accounting firms than in public bodies such as the Civil Service (Cooper Bros \& Co., 1954; Jones, 1995; Crowley, 2016). Pixley did not list the proficiencies of an accountant, thereby mystifying professional activity and rendering the skills associated with an accountant nebulous and difficult to replicate (Wilmott, 1986). 


\section{Accountancy, professionalisation and middle-class male masculinity}

In the opening decades of the twentieth century, Price Waterhouse adopted a hierarchical structure similar to that proposed by Pixley (1885), as noted by Jones (1995):

With its understated hierarchy based on occupation and class, the officers of Price Waterhouse have been likened to an extended family. Indeed, a respectful, gentlemanly atmosphere pervaded the building. (79-80).

The origins of a 'gentlemanly' masculine organisational culture in Price Waterhouse can be marked out to the early professionalisation of accountancy. Many middle-class men of the early nineteenth century developed networks of formal associations to promote their interests within the public sphere of work (Davidoff and Hall, 1987). In contrast, the wives of middle-class men tended to remain within the private sphere where they were institutionally subordinate to their husbands (Davidoff and Hall, 1987; Therborn, 2004). The formation of networks provided opportunities for the public demonstration of middle-class male achievement and responsibility. However, middle-class men did not exercise unfettered freedom in the public sphere, just as middle-class women were not totally confined to the domestic realm. Middleclass men were constrained by shifting forms of employment and competition for scarce jobs, as well as undertaking important roles in the domestic realm such as fatherhood (Tosh, 2005). Still, the gendered nature of the public-private divide enabled the accountancy profession to promote itself as an idealised environment for a gentlemen and a middle-class, gentlemanly masculinity, such as that described in Price Waterhouse above.

Significant in promoting and maintaining a middle-class male culture in accountancy was the formation of the ICAEW in 1880 from the five smaller associations that emerged in 
the decade earlier (Howitt, 1966). The ICAEW helped to elevate the social standing of accountancy (Macdonald, 1989), not least by encouraging a middle-class male interest in cultivating formal associations within the public sphere (Davidoff and Hall, 1987). The early accountants recognised the importance of this, which helped to increase the membership of the ICAEW from 154 in 1877 to 1,676 in 1890 (Howitt, 1966). The Cooper brothers were one such group of early accountants running a family accountancy business. The brothers recognised that whilst membership was important, leadership of the ICAEW was paramount, as it would raise their commercial profile. The obituary of one of the original founders of Coopers, Ernest Cooper, lauded his involvement with the ICAEW. He was appointed 'to the Council in 1891, Vice-President in 1898-1899, and President from 1899-1901' (Cooper Bros \& Co., 1954, 6). Similarly, his brother Arthur was a key figure in the ICAEW and when the accounting body received the Royal Charter in 1880, Arthur Cooper was one of the members of the first Council, Vice-President in 1882-1883, and President in 1883-1884 (Cooper Bros \& Co., 1954, 60). The early Coopers partnership realised the benefits to the firm if its partners secured prestigious, public positions, as exemplified by Arthur Cooper's position on the Council of the London Chamber of Commerce (Habgood, 1994).

Around the turn of the twentieth century, the professionalisation of accountancy was supported by processes used in other professions such as law (Witz, 1992), including membership, examinations and training articles (e.g. Pixley, 1885). Image management in accountancy was of particular importance at this time, as a means of convincing the business community of accountancy's equal status with the middle-class professions (Wilmott, 1986). For example, Price Waterhouse ensured that its staff sustained their male, middle-class professional image through a formal dress code;

Dress was formal in the late nineteenth century. Staff engaged on audits or other visits to clients were expected to wear a top hat and tail coat....while clerks who worked at 
Gresham Street wore bowler hats, short coats and had paper shields to protect stiffly starched shirt cuffs (Jones, 1995, 70).

This uniform helped to convey the accountant's respectability, success and skill. The early accountancy firms exploited social class lines to promote their profession. As Price Waterhouse's official biographer points out, as the only partner with a university education and membership of the upper-middle-class, Edwin Waterhouse possessed a range of social contacts not available to other members of his firm (Jones, 1995, 81). Edwin used his extensive school and family connections and country house to invite high status individuals to 'bring our profession a little before the public' (Jones, 1988, 139). The role of Edwin Waterhouse's wife was to assist him in the hosting process but when such invitations were reciprocated, it seems that men only were invited:

In 1894, the young Duke of Sutherland as a member of the L. and N.W. Railway board had included the auditors in an invitation to his colleagues to spend a night at Trentham. It was a gentleman's party, but we were introduced to the Duchess (ibid., 148).

In this extract, 'auditors' and 'gentleman' are used almost synonymously, reinforcing the desirability of the middle-class gentlemen as ideal professional accountant. Price Waterhouse retrenched its links with the upper-middle class through the recruitment of articled clerks from public schools, who paid a substantial premium (500 guineas) to train at Price Waterhouse, where they received no salary (Jones, 1995, 167). The articled clerks were treated as a 'privileged class' (Jones, 1995, 167). Indeed, until 1939, jobs at Price Waterhouse were not advertised. Personnel were engaged on the basis of a personal introduction (Jones, 1995, 236), which helped to reproduce the homogeneity of the ideal professional accountant as male and middle-class, to the exclusion of women and other men who could not meet this ideal. 


\section{Accountancy and the gendered division of labour before WW1}

As established above, while the gendered division of labour between men and women pre WW1 was structured by a spatial divide between the public and private realms, (Braybon and Summerfield, 1987), this did not mean women could not undertake any form of accountancy work and challenge their exclusion from the profession. During the nineteenth and the first half of the twentieth century, domesticity emerged as a dominant value system in Anglo-American culture (Walker, 1998), noted by Williams (1998) as being responsible for the creation of a hierarchical gender order, in which men were 'naturally' associated with the public sphere of work and women were understood to be 'natural' carers within the domestic sphere. Since men occupied the world of business and politics, it was assumed that middle-class women would use their time and moral capacity to be a positive influence on society from the domestic sphere (Davidoff and Hall, 1987). Consequently, many middle-class women concentrated their efforts on home-based or philanthropic activities (Davidoff and Hall, 1987). However, some middleclass women were called upon to carry out accountancy work.

For example, during busy times, the Cooper brothers enlisted the help of their two sisters, none of whom were ordinarily part of the accountancy business. Davidoff and Hall (1987) remark it was not a rare occurrence for dependent females to assist male family members in their economic enterprises, although they rarely received any public recognition and often no direct economic reward. In the case of the Cooper sisters:

...two or three of the sisters worked at home when a client of the firm arranged that these girls should check his books (Cooper Bros \& Co., 1954, 1). 
Within the context of a middle-class family business, the Cooper sisters, or 'girls' as they are referred to also, could undertake accountancy work but this was hidden from public view, confined to the home. Regulated in this way, accountancy work performed by the Cooper sisters retrenched the public-private gender divide between men and women.

Other women challenged the exclusionary practices of the accountancy profession. One of the most notable was Mary Harris Smith. Harris Smith repeatedly applied for membership to several accountancy bodies, including the ICAEW (Woman's Signal, 1 August 1895 cited in Walker, 2011, 213). With the support of the Society for Promoting the Employment of Women (SPEW) and the women's press, Harris Smith lobbied individual members of the ICAEW and council members, but to no avail (Walker, 2011). However, support arose from an unlikely source. Adopting a pro-equality stance on gender was uncommon amongst government departments, but the Board of Trade made the inclusion of women a condition of the Professional Accountants Bill 1911 (Walker, 2011), which would secure accountancy the highly valued statutory registration. The failure of the Bill in the House of Commons resulted in the ICAEW resuming its traditional exclusionary policy towards women (Walker, 2011, 204).

The Bill's demise can be attributed to a number of reasons such as the absence of female members of parliament until 1919 (Harrison, 1986) and anti-feminist discourses that circulated the idea that women were too weak to succeed in the workplace (Harrison, 1986). Indeed, one assertion voiced by male members of the accountancy profession was that women would struggle to practice public accountancy and could never be of equal status to male accountants (Shackleton, 1999). Ironically, women were often regarded and accepted as being 'the banker. . the president, the cashier, the teller, the discount clerk' within the family home (Talmage, 1890, 85 cited in Walker, 1998, 507). Notably, housekeeping in the early twentieth century was reconstructed in the UK as a 'profession' for middle-class women who 'could pursue a worthy 
career in the home and would no longer aspire to a vocation outside it' (Walker, 2003, 758). As Walker (2003) contends, while professionalisation promised to elevate the low status of housekeeping, it reinscribed the spatial dimensions of the gender divide by discouraging women from pursuing work careers outside the home.

The introduction of the Sex Disqualification (Removal) Act 1919 allowed women access to the professions and the civil service (Kirkham and Loft, 2013), and Harris Smith became the ICAEW's first female member in the following year (Walker, 2011). Harris Smith's prominence as the UK's first female chartered accountant did not open the floodgates for women to enter the ICAEW as many women struggled to secure the link between education and occupation (Walker, 2008). However, as the next section discusses, WW1 reshaped women's opportunities; at Coopers, 'Women were not employed until the 1914-18 war' (Cooper Bros \& Co., 1954, 27).

\section{WW1 and its impact on women in the accountancy profession}

During WW1, accountancy had to recruit women to compensate for those men lost to conscription. This is illustrated in the Accountant, which urged all accountancy firms to release men between the ages of 19 and 40 into the forces:

...undoubtedly a much larger number of accountants' clerks could be released from their present duties if... practitioners and their clients were to overcome a not altogether unnatural prejudice against the employment of women (The Accountant Vol. LVIII, No. 2272, 22 June 1918, 442, cited in Jones, 1995, 111). 
Losing male employees to the war effort opened up opportunities for middle-class women to access the accountancy profession. The following extract, referring to the impact of WW1 on Price Waterhouse, demonstrates this:

Women were employed at Price Waterhouse as secretaries and for clerical duties within Frederick's Place, though it does not appear that they were sent to the premises of clients on professional work (Jones, 1995, 114).

The recruitment of women into accountancy during this time was carefully controlled, mostly through personal recommendation and women were drawn from the middle-classes (Jones, 1995, 226). While female workers had a visible presence in the Civil Service during WW1 (Crowley, 2016), women in PwC were not permitted to perform accountancy work in the public domain, as the quote above suggests.

As some educated women began to fill accountancy positions during WW1, they were defined by gender first and occupation second; 'women working in accountants' offices', 'women clerks', 'lady assistants' and 'lady audit clerks' (Kirkham and Loft, 1993, 538). Women's roles in accountants' offices were constructed through their place in the gender hierarchy, differentiating them from the ideal of the male professional accountant. These women were constructed as a separate category of employee whose work was simplified to reflect the view of women's abilities at the time (Zimmeck, 1986; Black, 2006). While women had gained access to accountancy during wartime, the type of roles they performed, compared to women employed in the public sector (e.g. the Civil Service, Crowley, 2016) were very limited and ascribed low status. Female accountancy clerks were reminded by employers such as Price Waterhouse (Jones, 1995) that they would return to the home in peacetime, a stance supported by the government (Black, 2006, Crowley, 2016). Despite WW1 being recognised as a significant opportunity for women to enter the workplace (Braybon and Summerfield, 
1987), the presence of women in accountancy during this time did not appear to instigate a regendering of the profession as inclusive of femininity and women.

This can be evidenced by the normatively masculine terms used to describe accountancy organisations and its leaders: aggressive, competitive and efficient (Cooper Bros \& Co., 1954; Middleton, 1982; Wise, 1982; Jones, 1995). During wartime, accountancy firms were keen to imitate the language, practices and behaviours found in the military services to construct a heroic image of a rational, highly disciplined, aggressive male accountant (Wise, 1982). In the histories of the firms, accountants required 'integrity and courage' (Cooper Bros \& Co., 1954, Foreword v), or 'indomitable courage' (Middleton, 1982, 61) and 'moral courage to stick to opinions without fear of the consequences' (Cooper Bros \& Co., 1954, Foreword v). Similarly, accountancy firms were constructed as being run along the lines of a battalion with the partners acting as officers and the accountancy staff as the troops. This was not only a reflection of the War, but its cultural significance was that women were excluded from the front-line, deemed incapable of possessing the type of military masculinity being promoted and celebrated within accountancy. The culture of accountancy that traditionally had advocated a 'respectful, gentlemanly atmosphere' (Jones, 1995, 79-80), changed to reflect and endorse the wider militaristic culture of WW1. As can be seen in the quotes above, Cooper Bros \& Co. articulated the desirability of a militaristic male masculinity that appears to have displaced the gentlemanly male masculinity associated with accountant professionals pre-war.

\section{Women's post war employment in accountancy}


Women's employment in accountancy organisations largely came to an end with demobilisation (Cooper Bros \& Co., 1954). The accountancy profession and the government promoted ideology that compelled women to surrender their jobs to returning soldieraccountants. The latter were assisted with financial support and exemptions from preliminary examinations (Kirkham and Loft, 1993). Unlike public sector organisations such as the Post Office, which made women a 'central component' of their post-war labour plans (Crowley, 2016, 985), accountancy firms largely expelled women from the workplace (Black, 2006). This was the case at Coopers:

When the war was over, women were retained as shorthand writers, typists and telephonists, but the remainder were gradually replaced by men returning from the Forces (Cooper Bros \& Co., 1954, 27).

As Kirkham and Loft (1993) submit, gendered ideology at the time portrayed returning service men as heroes and warriors. Women, meanwhile, were praised for their submissiveness and willingness to subordinate themselves to the returning male soldiers, which had the effect of reinstating a traditional gendered division of labour across the public-private divide.

Notably, some women managed to remain within accountancy but this was conditional: they had to appear single and perform secretarial roles that supported male accountants (Jones, 1995). The following extract indicates this was the case at Price Waterhouse:

The return of the troops in 1919 resulted in about two-thirds of those women who had found work during the War being made redundant. Yet a number of accountancy firms, glad of their secretarial competence, retained their services. Price Waterhouse employed a number of women during the twenties, stipulating that they must be single. Some who had married concealed this fact from their employer (by removing their wedding rings in the office) in order to retain their posts (Jones, 1995, 115). 
Price Waterhouse adopted work practices already implemented in the Civil Service, such as the imposition of the marriage bar, a legal instrument used by public and private sector organisations to dismiss women from work upon marriage (Glew, 2016). As the quote above suggests, some married women in Price Waterhouse tried to get round the marriage bar by concealing their married status, in order to protect their job and income. Another work practice common to accountancy and the Civil Service was the allocation of the typist role to women (Glew, 2016). Women achieved almost total domination of this job category in accountancy, holding $97.6 \%$ of available posts by 1931 (Kirkham and Loft, 1993, 546). This job was regarded as involving repetitive, mechanistic skills, the very attributes Pixley (1885) had categorised as being diametrically opposed to those required of an accountant. However, mechanisation, including the use of adding machines or comptometers, started to impact on the accountant's office and it allowed a lower entry point for women, as it was assessed that 'an intelligent girl with a machine might easily, from the point of view of fee earning, become equivalent of at least one junior (man)' (Jones, 1995, 166).

In the post war years, the ideal professional accountant appeared to remain heavily associated with middle-class men and masculinity. While female employees were being segregated into secretarial and other low status accountancy jobs, presenteeism continued to be a particularly prominent characteristic of a professional accountant's job (Coopers Bros \& Co., 1954; Jones, 1995). The working hours of accountancy staff were and had always been long: 'from nine in the morning until six in the evening during the week and from nine until two in the afternoon on Saturday' (Cooper Bros \& Co., 1954, 25). But it was male accountants who could more easily demonstrate their dedication to the profession through working long hours, which served also as an organisational symbol of their productivity. Women continued to shouldered responsibility for managing the domestic sphere post war, restricting them from undertaking long hours in the workplace, even if they wished to (D’Cruze, 2002). 
An illustration of the time commitment required of accountancy workers is provided by the retired senior partner of Coopers, S. John Pears, who started working for the business in 1919: 'Later, I worked, lived and slept Coopers: I had almost no life but Coopers' (Accountancy, 1972, 18). Further feats of work endurance are remarked upon by Pears in his reflections on his work life in Coopers (no date provided):

Henry and I headed a team that worked all night on a rescue operation.... We completed consolidated accounts (this had not been done before) for 34 companies, working day and night throughout Easter, only breaking off once a day to play squash to keep ourselves awake (ibid.).

As the extract above shows, the ability to endure such long hours of work is constructed as a heroic feat and bonding exercise between men. It conveyed to the client what a difficult job accountancy was. Similar patterns of time commitment, indicating dedication to the role of accountant, are found in the historical archives of other accountancy firms during the period (Wise, 1982, 2). One implication of the emphasis Coopers placed on working long hours was that it demanded a professional accountant who, ideally, had no family commitments or had someone to take responsibility for those commitments, such as a wife. Women's domestic duties impinged on their ability to work long hours and, as one result of this they struggled to ascend career ladders in the accountancy profession during the post war years (Matthews and Pirie, 2001), and subsequent decades (Crompton and Lyonette, 2011; Whiting et al., 2015).

\section{Conclusion}


The professionalisation of accountancy from the 1870s to the interwar years represents a key time period in the reproduction of gender inequality in accountancy, not least because of its role in (re)constructing the ideal professional accountant as male and masculine. One principal contribution this article makes to historical scholarship on gender and accountancy is the synthesis of feminist theory with a deep and wide historical context to examine how the professionalisation of accountancy is a gendered process. Historically specific power relations are important to analyse in that regard, and business historians are in a privileged position to undertake this research, especially as Durepos, McKinlay and Taylor $(2017,1261)$ argue, in this journal, that women are 'often described as partially or completely excluded from business histories'. While pro/feminist business historians have started to account for gender in the histories of UK accountancy firms (Lehman, 1990; Shackleton, 1999; Walker, 2008), and in the professionalisation of accountancy (Kirkham and Loft, 1993; Walker, 2011), this scholarship has yet to explore fully the value of specific feminist theories, such as Acker's (1990) theory of the ideal worker.

In this article, Acker's (1990) writing on the ideal worker enables a close examination of historical gendered power relations at work within $\mathrm{PwC}$, and how they (re)shape the construction of the ideal professional accountant. Through adopting this angle, the article provides empirical insights into how the ideal professional accountant at PwC was (re)constructed as male and masculine through the gendering of the skills and knowledge demanded of the professional accountant (Pixley, 1885), image management (Jones, 1995), networking (Jones, 1988) and the emphasis placed on social class (Howitt, 1966). The relevance of mobilising social class as a category of historical analysis along with gender has been illustrated using historical data that shows how the ideal professional accountant in PwC became associated with middle-class men, while those women who were able to gain employment in accountancy in $\mathrm{PwC}$ were drawn also from the middle-classes. By taking 
gender and class into account, business historians can learn a lot more about the nature of the exclusionary and inclusionary logics underpinning the early process of professionalisation in accountancy.

Another contribution this article makes is to show how the ideal professional accountant construct is shaped by wider social changes affecting the accountancy profession. For example, data presented above supports Braybon and Summerfield's (1987) argument that WW1, and the period thereafter, largely solidified gendered pre-war norms about the roles of women and men within the public and private realms. In the case of $\mathrm{PwC}$, historical evidence suggests that although PwC employed women during wartime, this did not effect a re-gendering of the firm that was inclusive of femininity and women. Rather, in the case of $\mathrm{PwC}$, and other accountancy firms (Middleton, 1982), during WW1 the expression of militaristic masculinity amongst accountancy professionals can be seen as desirable, in order to support the war effort. Nonetheless, this article has shown also how women's confinement to the domestic sphere was not totalising, in both pre-war and post war periods, as women like Harris Smith sought to challenge and overcome the exclusionary practices of the accountancy profession. Through studying the personnel practices that were adopted in response to social changes such as WW1 and the introduction of the marriage bar, the $\mathrm{PwC}$ case study can help business historians to understand how the professionalisation of accountancy relied upon organisational practices that had specific, sometimes unexpected, gendered implications for women and men.

\section{References}

Accountancy (1972). Fifty-two years at Coopers July 1972, Vol. 83 Issue 947, p17-21: CCH

Acker, J. (1990). Hierarchies, jobs, bodies: A theory of gendered organizations. Gender \& society, 4(2), 139-158. 
Acker, J. (2006). Inequality regimes: Gender, class, and race in organizations. Gender \& society, 20(4), 441-464.

Aulakh, S., Charlwood, A., Muzio, D., Tomlinson, J., \& Valizade, D. (2017). Mapping advantages and disadvantages: Diversity in the legal profession in England and Wales. Final Report for the Solicitors Regulation Authority.

Allen, D. G., \& McDermott, K. (1993). Accounting for success: A history of Price Waterhouse in America, 1890-1990. Harvard Business Press.

Anderson-Gough, F., Grey, C., \& Robson, K. (2005). "Helping them to forget..": the organizational embedding of gender relations in public audit firms. Accounting, Organizations and Society, 30(5), 469-490.

Black, J. (2006). War, women and accounting: Female staff in the UK Army Pay Department offices, 1914-1920. Accounting, Business \& Financial History, 16(2), 195-218.

Braybon, G., \& Summerfield, P. (1987). Out of the cage: Women's experiences in two world wars. Routledge.

Burr, V. (2015). An introduction to social constructionism. (3 ${ }^{\text {rd }}$ ed.) Routledge.

Ciancanelli, P., Gallhofer, S., Humphrey, C., \& Kirkham, L. (1990). Gender and accountancy: Some evidence from the UK. Critical Perspectives on Accounting, 1(2), 117-144.

Cooper Bros \& Co. (1954). A History of Cooper Brothers \& Co 1854 to 1954 London: Batsford for Cooper Bros \& Co.

Crompton, R. and Lyonette, C. (2006) Work-life 'balance'in Europe Acta Sociologica, 49(4), 379-393.

Crompton, R., \& Lyonette, C. (2011). Women's career success and work-life adaptations in the accountancy and medical professions in Britain. Gender, Work \& Organization, 18(2), 231254.

Crowley, M. J. (2016). 'Inequality'and 'value'reconsidered? the employment of post office women, 1910-1922. Business History, 58(7), 985-1007.

Davidoff, L., \& Hall, C. (1987). Family fortunes: Men and women of the English middle class 1780-1850. Routledge.

Durepos, G., McKinlay, A., \& Taylor, S. (2017). Narrating histories of women at work: Archives, stories, and the promise of feminism. Business History, 59(8), 1261-1279.

D'Cruze, S. (2002). Women and the family, in J. Purvis (ed.), Women's History: Britain, 18501945, Routledge: London, 51-84. 
Elston, M. A. (1993) Women doctors in a changing profession: the case of Britain in Riska, E., \& Wegar, K. (Ed), Gender, work, and medicine: women and the medical division of labour (Vol. 44) 27-61. Sage Publications Ltd.

Evans, C. (2016). Accounting for Gender: A historical evaluation of the gendered hierarchy of the $U K$ accounting profession $\mathrm{PhD}$ Thesis, University of Roehampton. Retrieved from https://pure.roehampton.ac.uk/portal/en/studentthesis/accounting-for-gender(bc134a42-24114078-8f0b-fc19c92e38bc).html

FRC (2018). Key Facts and Trends in the Accountancy Profession. Retrieved 8 August 2019 from https://www.frc.org.uk/getattachment/27725654-8bd9-4623-a410-ef1661a69649/KeyFacts-and-Trends-2018.pdf.

Glew, H. (2016). Gender, rhetoric and regulation: women's work in the Civil Service and the London County Council, 1900-55. Manchester: Manchester University Press.

GMC (2017). The state of medical education and practice in the UK: London. Retrieved 19 August 2019, from https://www.gmc-uk.org/static/documents/content/SoMEP-2017-finalexecutive-summary.pdf.

Habgood, W. (Ed.). (1994). Chartered accountants in England and Wales: a guide to historical records. Manchester University Press.

Harrison, B. (1986). Women in a Men's House the Women MPs, 1919-1945. The Historical Journal, 29(3), 623-654.

Haynes, K. (2008). Moving the gender agenda or stirring chicken's entrails? Where next for feminist methodologies in accounting?. Accounting, Auditing \& Accountability Journal, 21(4), 539-555.

Howitt, H. (1966). The History of the Institute of Chartered Accountants in England and Wales, 1880-1965: and of its founder accountancy bodies, 1870-1880: the growth of a profession and its influence on legislation and public affairs. Heinemann.

Jones, E. (Ed.). (1988). The Memoirs of Edwin Waterhouse: A Founder of Price Waterhouse. BT Batsford Limited.

Jones, E. (1995) True and Fair: A History of Price Waterhouse Hamish Hamilton Ltd

Khalifa, R. (2013). Intra-professional hierarchies: the gendering of accounting specialisms in UK accountancy. Accounting, Auditing \& Accountability Journal, 26(8), 1212-1245.

Kirkham, L. M., \& Loft, A. (1993). Gender and the construction of the professional accountant. Accounting, Organizations and Society, 18(6), 507-558.

Kokot, P. (2015). Let's talk about sex (ism): Cross-national perspectives on women partners' narratives on equality and sexism at work in Germany and the UK. Critical Perspectives on Accounting, 27, 73-85. 
Law Society (2018). Annual Statistics Report 2017. Retrieved 20 August 2019, from https://www.lawsociety.org.uk/law-careers/becoming-a-solicitor/entry-trends/

Lehman, C. R. (1990). The importance of being earnest: gender conflicts in accounting. Advances in Public Interest Accounting, 3, 137-157.

Macdonald, K. M. (1989). Building respectability. Sociology, 23(1), 55-80.

Matthews, D. and Pirie, J. (2001). The Auditors Talk: An Oral History of a Profession from the 1920s to the Present Day. New York: Garland Middleton, S.A.

A history of the Northern Society of Chartered Accountants. (1982) Newcastle-upon-Tyne: Northern Society of Chartered Accountants.

Nicolson, D. (2005). Demography, discrimination and diversity: a new dawn for the British legal profession? International Journal of the Legal Profession, 12(2), 201-228.

Pilcher, J. (1999) Women in contemporary Britain: an introduction Routledge: LondonPixley, F.W. (1885) Profession of a Chartered Accountant and Other Lectures: Delivered to the Institute of Chartered Accountants in England and Wales published in 1978 Ayer Co. Publishers.

Sayce, S. (2012). Celebrating Joan Acker's contribution to theorising gender and organisation. Equality, Diversity and Inclusion: An International Journal, 31(3), 205-207.

Scott, J. (1986). American Historical Review. Gender: a useful category of historical analysis, 91, 1053-1075.

Shackleton, K. (1999). Gender segregation in Scottish chartered accountancy: the deployment of male concerns about the admission of women, 1900-25. Accounting, Business \& Financial History, 9(1), 135-156.

Sikka, P., \& Willmott, H. (1995). The power of "independence": defending and extending the jurisdiction of accounting in the United Kingdom. Accounting, organizations and society, 20(6), 547-581.

Suddaby, R., Cooper, D. J., \& Greenwood, R. (2007). Transnational regulation of professional services: Governance dynamics of field level organizational change. Accounting, organizations and society, 32(4-5), 333-362.

Therborn, G. (2004). Between sex and power: Family in the world 1900-2000. Routledge.

Tosh, J. (2005). Masculinities in an industrializing society: Britain, 1800-1914. Journal of British Studies, 44(2), 330-342.

Walker, S. P. (1998). How to secure your husband's esteem. Accounting and private patriarchy in the British middle class household during the nineteenth century. Accounting, Organizations and Society, 23(5-6), 485-514. 
Walker, S. P. (2003). Professionalisation or incarceration? Household engineering, accounting and the domestic ideal. Accounting, Organizations and Society, 28(7-8), 743-772.

Walker, S. P. (2008). Accounting histories of women: beyond recovery?. Accounting, Auditing \& Accountability Journal, 21(4), 580-610.

Walker, S. P. (2011). Professions and patriarchy revisited. Accountancy in England and Wales, 1887-1914. Accounting History Review, 21(2), 185-225.

Whiting, R. H., Gammie, E., \& Herbohn, K. (2015). Women and the prospects for partnership in professional accountancy firms. Accounting \& Finance, 55(2), 575-605.

Williams, J. (2000). From difference to dominance to domesticity: care as work, gender as tradition. Chi.-Kent L. Rev., 76, 1441.

Williams, J.C. (1998). Toward a Reconstructive Feminism: Reconstructing the Relationship of Market Work and Family Work. N. Ill. UL Rev., 19, 89.

Willmott, H. (1986). Organising the profession: a theoretical and historical examination of the development of the major accountancy bodies in the UK. Accounting, Organizations and Society, 11(6), 555-580.

Wise, T. A. (1982). Peat, Marwick, Mitchell \& Co: 85 years. Peat, Marwick, Mitchell.

Witz, A. (1992). Professions and patriarchy (International library of sociology). Routledge.

Zimmeck, M. (1986). Jobs for the Girls: the Expansion of Clerical Work for Women, 18501914, in A.V. John (ed.), Unequal opportunities, Women's Employment in England 1800-1918 Basil Blackwell Ltd: Oxford, 153-178. 